\title{
Marked Geminates as Evidence of Sonorants in Sylheti Bangla: An Optimality Account
}

\author{
Arpita GOSWAMI \\ Kalinga Institute of Industrial Technology, India \\ arpig99@gmail.com
}

\begin{abstract}
This paper analyzes the universal concept that sonorants are marked geminates in the gemination process of Sylheti Bangla (henceforth SHB). Evidence from SHB suggests that when SHB speakers confront borrowed words with sonorant initial or obstruent initial heterosyllabic clusters, it is invariably the sonorant that gets assimilated. In addition, SHB data indicates that when faced with choices between two sonorants of the heterosyllabic clusters, speakers opt for the less sonorous one for gemination. Given this phenomenon, the proposal that sonorant gemination is absent in SHB could not be the ultimate one as it receives additional support from the fact that SHB also possesses many underlying sonorant geminations. Based on this investigation the hierarchy of the constraints *GG*RR > ${ }^{*} L L^{*} N N$ is proposed for analyzing the gemination process in SHB. Finally, this paper illustrates some additional constraints in the SHB gemination process found to be necessary.
\end{abstract}

Keywords: gemination; sonorant; obstruent; constraints; optimality theory

\section{Povzetek}

Članek analizira univerzalni koncept, da so zvočniki zaznamovani soglasniki $v$ procesu podvojevanja v silheti bengalščini (odslej SHB). Podatki iz SHB kažejo, da so v izposojenkah z raznozložnim soglasniškim zaporedjem, vedno zvočniki tisti, ki so podvrženi prilikovanju (asimilaciji). Soglasniško podvojevanje zaradi prilikovanja se vedno zgodi v prid manj zvočnega soglasnika. Posledično torej predlog, da v SHB ni podvojenih zvočnikov, ni ustrezen, saj je podvojena zvočnika pojavljata v globinski podstavi. Na podlagi raziskave predlagamo naslednjo hierarhija omejitev ${ }^{*} G G * R R>{ }^{*} L L^{*} N N$ za analizo procesa podvojevanja $v$ SHB. Članek $v$ zaključku ponazarja nekatere dodatne omejitve v postopkih geminacije SHB, za katere je bilo ugotovljeno, da so potrebne.

Ključne besede: podvojevanje; zvočnik; nezvočnik; omejitve; optimalnostna teorija 


\section{Introduction}

One of the most significant discoveries in the field of loanword adoption is the speakers' distinct propensity to modify the borrowed words employing a varied range of phonological phenomena such as epenthesis, deletion, gemination, etc. to obtain unmarked structures. This paper explores one such predominant phonological phenomenon of gemination process applied by the Sylheti speakers. Gemination has already been defined by several linguists. Catford (1977, p. 277), for example, views the articulation of gemination as involving "a higher articulatory effort accompanying the act of moving and holding the articulators to maintain a longer occlusion time for the geminate contoid", whereas Davis (2011a) states that geminates or 'double consonants' contrast with their 'singleton' part. Following Ladefoged \& Maddieson (1996), Pajak writes that "cross-linguistically, geminates are on average between one-and-a-half to three times as long as singletons" (2009, p. 269).

Many languages across the world contain geminate consonants such as Arabic, Berber, Estonian, Finnish, Cypriot Greek, Hindi, Hungarian, Italian, Japanese, Malayalam, Persian, Saami, Swiss German, Turkish, etc. (Kubozono, 2017). Crosslinguistic evidence shows that the presence of gemination in the intervocalic position is very frequent, while it is rare when not adjoining to any vowel (Kubozono, 2017). Elucidating the reason Pajak (2009) claims that the contrast between singletons/geminates in the intervocalic position is perceptible, on the contrary, when gemination is adjacent to a consonant, this contrast is less perceptible.

A rigorous investigation of $\mathrm{SHB}$ data is indicative of the fact that a certain number of geminated words emerge in SHB through the modification of borrowed words consist of obs+son or son+obs or son+son clusters. Another variation noticed in SHB gemination is derived from the borrowed words include a CV.CV or CV.CVC structure into a geminate structure CVC.CV or CVC.CVC. In such instances, the onset of the final syllable gets geminated and acts as a coda of the first syllable. In all the gemination processes, SHB follows the typological trend in admitting the occurrence of gemination only in the intervocalic position. Edge geminates are prohibited in SHB since the constraint *COMPLEX holds a prominent position in this variety of Bangla. Additionally, the facts of SHB gemination also demonstrate that it corroborates the cross-linguistically established view that sonorant sounds are less preferable than geminate consonants.

The cause of the dispreference of sonorant geminates relies on the core principle of Adaptive Dispersion Theory (Lindblom, 1986; Flemming, 1996, 2004; Ito \& Mester, 2006), which is "an attempt to model typology of phonological inventories as a set of elements evenly spaced (or 'dispersed') in an acoustic-perceptual way" (Ito \& Mester, 2006, p. 666). According to Flemming, the selection of phonological contrast is based on three main principles: 1. maximize the number of contrasts, 2. maximize the distinctiveness of contrasts, and 3. minimize articulatory effort, adding that "the existence of such constraints implies that the well-formedness of a word cannot be evaluated in isolation, 
it must be evaluated regarding a set of forms that it contrasts with" (Flemming, 1996, p. 1). Further, in one of his other works Flemming (2004, p. 15) writes that "the auditory distinctiveness of the contrasts should be maximized so that the differences between words can easily be perceived by a listener, minimizing confusion". If the realization of contrast between phonemes is insufficiently distinct, it can be neutralized or modified to make it more distinct. For instance, in the case of vowels if the vowels are well distributed in the acoustic zone they are considered as preferable phonemes, but those candidates whose dispersion in the acoustic space is partial, have less chance to be treated as phonemes in languages. Taking this theory into account, many previous works such as Kawahara (2007) and Kubozono (2017) explain that languages avoid sonorant geminates because, in the case of sonorant sounds, the segmental boundaries are not distinct which causes difficulties in perceiving the segmental duration of sonorants. Since the basis of a phonological geminacy contrasts is the constriction duration between singletons and geminates, and the constriction of sonorant segments is hard to perceive, as such they do not make a very perceptible minimal pair. To encapsulate, it could be generalized that as the contrasts between singleton and geminates sonorants are difficult to discriminate perceptually, languages prefer avoiding sonorant geminates.

Turning now to SHB, it is noteworthy that the most geminable candidates in SHB are obstruents, nasals, while laterals are less geminable, and glides and rhotics are not geminable at all. Based on this hierarchy, the ranking of constraints proposed for SHB gemination is *GG *RR>>*LL *NN>>*OBSGEM. In this paper, I will illustrate all the variations of gemination that occur in $\mathrm{SHB}$, and their relative constraints with the help of Optimality Theory (Prince \& Smolensky, 1993/2004; Kager, 1999). Data for this research were collected from the spontaneous speech by Sylheti speakers from in and around the Dharmanagar district of North Tripura and transcribed. The collected data were crosschecked with the researcher's native language's knowledge and intuition.

\section{Sonorants are marked geminates}

The segmental composition of geminates has always been an interesting topic to linguistic research from the phonetic as well as phonological point of view. One of the most significant findings was the fact that in the case of gemination, languages display their preference for obstruents over sonorous segments. After having surveyed geminate consonants in many languages, Taylor (1995, p. 122) revealed that "[s]ince all 28 languages.... have at least one obstruent geminate..., if a language has at least one geminate sonorant, it will also have one geminate obstruent".

Having conducted a cross-linguistic survey to experiment with the nature of geminate consonants in languages of the world, Podseva (2002) hypothesized that languages display dispreference for sonorant geminates since 'the sonorant geminates are easily confused with corresponding singletons' and this problem occurs because 
'sonorants are spectrally continuous with flanking vowels, and consequently their constriction duration is difficult to perceive' (Kubozono, 2017). The following languages demonstrated in Table 1 are surveyed by Podseva (2002) to investigate the status of geminate sonorant in the languages of the world.

Table 1: Status of geminate sonorant in the languages of the world

\begin{tabular}{lccccc}
\hline & Nasals & \multicolumn{2}{c}{ Liquids } & Glides \\
\cline { 3 - 5 } & & & laterals & rhotics \\
\hline 1. Finnish, Hindi, Icelandic, Karo Batac, Maithili, & $\checkmark$ & $\checkmark$ & $\checkmark$ & $*$ \\
Persian, Ponapean, Somali, Tiyre, Toba, Batak & & & & \\
2. Punjabi, Selkup, Yakut, Fula & $\checkmark$ & $\checkmark$ & $*$ & $*$ \\
3. Chaha, Japanese, LuGanda, Maranungku & $\checkmark$ & & & $*$ \\
4. !Xo'o & $\checkmark$ & $*$ & $*$ & $*$ \\
5. Biblical Hebrew, Wolof & $*$ & $*$ & $*$ & $*$ \\
\hline
\end{tabular}

While Podseva's work was based on a hypothesis, Kawahara (2007) conducted an experimental study on the nature of geminate consonants. In his work, Kawahara demonstrated how languages across the world apply phonological processes such as degemination, occlusivization, coda nasalization, etc. to ignore sonorant gemination, and concluded that sonorants are less preferred segments for gemination. Explaining the reason behind the dispreference of sonorant geminates, he stated that the contrast of phonological geminacy is based "on a constriction duration difference between singletons and geminates", and due to the "blurry transitions into and out of flanking vowels, sonorants have a disadvantage in signaling their duration" (Kawahara, 2007, p. 2). It is therefore difficult to perceive sonorant geminates accurately. Kawahara also pointed out that the blurriness of the segmental boundary is not the only reason behind the difficult perception of sonorant geminates. One of the further factors is amplitude and its changes, which 'are steep for the stops but shallow for the sonorants', and make the perception of the segmental boundary of sonorants more difficult. Yet another factor that inhibits the perception of sonorant boundary is the 'stretched out' of the cues of sonorant segments (Kawahara, 2007).

Now I will briefly discuss how Kawahara (2007) cited examples from different languages' application of phonological processes to resolve sonorant gemination which evinces sonorants are marked candidates for gemination. Luganda allows obstruent gemination as in $/ \mu+k u b /=/ k k u b o /$ 'path', but when consonants in the initial position of the syllable are liquids or glides, occlusivization is applied to avoid sonorant geminates as in $\mu$-wangal $\rightarrow$ [ggwaanga] 'nation'. Following Whitney (1889), he mentioned that Sanskrit completely disallows retroflex untrilled liquid [ $r$ ] gemination. Due to this fact, in Sanskrit geminate approximants undergo degemination, for example, [punar+ramate] $\rightarrow$ 
[puna:ramate] *[punarramate]. However, fricative, stop gemination, and other types of sonorant gemination such as laterals, nasals are allowed in Sanskrit for example, asse, arkka, etc. In the line of Sanskrit, Greek also applies degemination to avoid sonorant geminates. Unlike Sanskrit, Greek also degeminates nasal gemination. In Japanese, when a mimetic suffix /-ri/ is placed with a floating mora, it causes gemination for examples, $/$ bata- $\mu$-ri/ $\rightarrow$ [batta-ri] 'accidentally', /poka- $\mu$-ri/ [pokka- ri] 'openly'. However, in the case of root-final syllables with liquids or glides, degemination takes place, and a coda nasal occurs as in /kira+N+ri/ $\rightarrow$ [kiNra-ri] 'shiningly'. In Selayarese, gemination is formed when the root with voiceless obstruent as initial consonant is preceded by the prefix /ta?/, such as /ta?+tuda/ [tattuda] 'bump against', /ta? + kalup/ [takkalup] 'faint', but when the root begins with nasals and liquids, the gemination gets blocked for instance, /ta? + muri/ [ta?muri] 'smile'.

The phenomena applied to ignore sonorant geminates cited in (Kawahara, 2007) are mentioned below.

a. occlusivisation (Berber, Luganda)

b. coda nasalization (Japanese)

c. degemination (Greek, Sanskrit)

d. floating mora flopping (Japanese)

e. blocking of gemination (Ilokano, Selayarese)

Misperception is the main reason that results in the phonological processes triggered by constraints against geminate sonorants.

Table 2: List of phonological processes used in the languages of the world

\begin{tabular}{llcccc}
\hline Processes & Language & \multicolumn{3}{c}{ Geminate types avoided } \\
\cline { 2 - 5 } & & Obst. & Nasal & Lateral & Glide \\
\hline Occlusivization & Berber & $\checkmark$ & $\checkmark$ & $\checkmark$ & $*$ \\
& LuGanda & $\checkmark$ & $\checkmark$ & $*$ & $*$ \\
Nasalisation & Chaha, Endenzen \&, Ezha & $\checkmark$ & $\checkmark$ & $*$ & -- \\
Coda nasalization & Japanese & $\checkmark$ & $\checkmark$ & -- & $*$ \\
Floating mora flopping & Japanese & $\checkmark$ & $*$ & -- & $*$ \\
Degemination & Sanskrit & $\checkmark$ & $\checkmark$ & $\checkmark$ & $*$ \\
Blocking of gemination & Greek & $\checkmark$ & $*$ & $*$ & $*$ \\
& Slokano & $\checkmark$ & $\checkmark / *$ & $\checkmark / *$ & $*$ \\
\hline
\end{tabular}

$\checkmark$ indicates the presence of sonorant sounds used as geminated ones in the mentioned languages

* indicates avoidance of sonorants as gemination in the mentioned languages

-- indicates the absence of sonorant sounds in the mentioned languages, so, it can not be stated whether they undergo gemination or not.

$\checkmark / *$ indicates marginal use of sonorant sounds 


\section{An Overview of Sylheti Bangla}

Sylheti Bangla is primarily spoken in the Sylhet District located in the North-Eastern region of Bangladesh. It is also spoken in the three states of India - Tripura (the North Tripura district), Assam (the Barak Valley), and Meghalaya. Outside Bangladesh or India, SHB is also widely spoken in the United Kingdom. For the current paper, Sylheti spoken by the people of North Tripura is surveyed and examined. Tripura is a state of Northeast India bordered by Bangladesh to the north, south and west, and the Indian states of Assam and Mizoram to the east. During the time of independence of Bangladesh (1971), an influx of inhabitants of Sylhet District with Sylheti tongue entered India due to the political turmoil in Bangladesh, and many of them as refugees made their residence in the North District of Tripura. These people were gradually rehabilitated in Tripura as citizens of India. For that reason, in the North Tripura District SHB is spoken by the people who ancestrally belong to the Sylhet District of Bangladesh, and in this way, the particular variety of Bangla became the sole language of communication in the North part of Tripura Especially in and around Dharmanagar.

SHB falls in the south-east group of Bangla dialects. However, it was formerly written in its script, Sylheti Nagari, similar in style to Kaithi (a script that belongs to the main group of North Indian scripts used in Bihar). Many scholars also find the affiliation of Sylheti with the Kamrupi group due to some interesting characteristics of this dialect which are found only in the Kamrupi group. Other characteristics can be called the exclusive property of East Bangla. Hence, nowadays it is almost invariably written in Bangla script. Approximately $70 \%$ of the Sylheti vocabulary is considered to have derived from Arabic, Persian, Hindi, Assamese, and some of the other Bangla dialects.

A close observation of SHB data reveals that a significant number of geminated words emerged in SHB through the modification of borrowed words. When SHB speakers confront consonant clusters appears in the word boundary combining of obstruent+sonorant, they tend to geminate obstruent candidate. The examples of SHB gemination are demonstrated as follows.

Table 3: Gemination from obst+son medial clusters

\begin{tabular}{|c|c|c|}
\hline $\begin{array}{l}\text { Borrowed words with } \\
\text { obst+son medial clusters }\end{array}$ & Gemination in SHB & Gloss \\
\hline aț.ma & at.ta & 'soul' \\
\hline kon.ya & xoin.na & 'would be bride' \\
\hline bon.ya & boin.na & 'flood' \\
\hline cok.ro & sak.ka & 'wheel' \\
\hline pod.mo & ф)d.d. & 'lotus' \\
\hline$c^{h}$ ot.ro & saț.ti & 'umbrella' \\
\hline Juk.ro & huk.kur & 'Friday' \\
\hline pot.ro & фat.ta & 'leaf’ \\
\hline
\end{tabular}


The preference of obstruents over sonorants in Table 3 can be attributed to the Syllable Contact Law (Vennemann, 1988, Davis, 1998, Gouskova, 2000) which proposes that sonority creates a bad contact in case it rises across the syllable boundary. Henceforth, to respect this law, the onset of the final syllable gets assimilated to the former. Besides these examples, there are some other geminated words that emerged in SHB from the alternation of borrowed words consisting of heterosyllabic consonant clusters of sonorant + obstruent segments. Consider the following examples in Table 4.

Table 4: Gemination from son+obs medial clusters

\begin{tabular}{lll}
\hline $\begin{array}{l}\text { Borrowed words with } \\
\text { son+obst medial cluster }\end{array}$ & Gemination in SHB & Gloss \\
\hline kir.ton & kit.ton & \\
kar.tik & kattik & 'devotional song' \\
bor.di & bod.di & 'name of Hindu God' \\
Jorța & hot.ta & 'elder sister' \\
kur.ji & kuf.fi & 'bettele nut cutter' \\
bor.ja & bof.Ja & 'chair' \\
dur.ba & dub.ba & 'name of a Bengali month' \\
\hline
\end{tabular}

In the data set in Table 4, consonant cluster combinations are the examples of either falling or equal sonority, and thus obey the Syllable contact law. However, in these cases also like the previous one (data set 3 ) sonorant sounds get assimilated, and obstruents are susceptible to any change. There thus should be other reasons behind the dispreference of sonorant gemination in SHB which will be discussed later.

From the example set $(3,4)$, it is evident that when the borrowed words with heterosyllabic cluster consist of a sonorant + obstruent combination, or an obstruent + sonorant combination, it is invariably the sonorant sound in the syllable which is more prone to assimilation. In SHB, we do not observe examples of glides and rhotics gemination. However, we can not conclude that SHB is completely devoid of sonorant geminates. For instance, when borrowed words are composed of a sonorant + sonorant sequence, the less sonorous one dominates the more sonorous one. The following examples in Table 5 illustrate this point. 
Table 5: Gemination from son+son medial clusters

\begin{tabular}{|c|c|c|}
\hline $\begin{array}{l}\text { Borrowed words with } \\
\text { son+son medial clusters }\end{array}$ & Gemination in SHB & Gloss \\
\hline pur.no & фun.nว & 'complete' \\
\hline$g^{\text {hur.ni }}$ & gun.ni & 'whirl’ \\
\hline kon.ya & xoin.na & 'daughter' \\
\hline pur.ni.ma & фun.ni & 'full moon' \\
\hline
\end{tabular}

Apart from this, SHB also contains underlying nasal and lateral geminations as cited in the following examples in Table 6.

Table 6: Lateral and nasal gemination in SHB

\begin{tabular}{ll}
\hline Lateral and nasal geminates in SHB & Gloss \\
\hline gul.li & 'bullet' \\
til.la & 'hill' \\
gul.la & 'round' \\
gin.na & 'hate' \\
hun.no & 'zero' \\
ul.laJ & 'enjoyment' \\
al.la & 'God' \\
\hline
\end{tabular}

Now the question arises why do SHB speakers disallow rhotic and glide gemination, and on the other hand allow nasal and lateral gemination. The Complexity Condition theory could help to elucidate this point. The theory states that if a segment's sonorous value is high, it indicates that the segment has greater complexity (Rice, 1992), and the complex segments are more prone to the violation. In the ladder of the sonority hierarchy, the least sonorous segment is obstruent and vowel carries the status of the most sonorous segment. The universally accepted sonority scale is provided in Figure 1.

vowels $>$ glides $>$ liquids $>$ nasals $>$ obstruents

Figure 1: Modal Sonority Hierarchy (e.g. Clements, 1990; Kenstowicz, 2004)

In the light of the Complexity Condition theory, it could be stated that rhotics and glides are more complex than laterals and nasals due to their greater sonority value. A similar phenomenon is viewed in the Pali language (Dutta, 2017). In Pali, the borrowed words from Sanskrit underwent phonological process gemination where the most 
sonorous sounds get assimilated, and the less sonorous sounds retain their existence in the syllable. Like SHB, in Pali also when the borrowed words consist of liquid or glide plus nasal or lateral it is always the rhotic or glide sounds that get assimilated, and lateral or nasal get priority over them. Some instances of Pali gemination are cited here.

kərmə kəmmə 'work' (Dutta, 2017)

muljə mullə 'price'

The above-mentioned Pali geminate instances point out that when the segment is more complex, it is more prone to violation.

Another variety of gemination present in SHB emerges from the phonological alternation of borrowed words include a CV.CV or CV.CVC syllable structure. In such cases, the onset of the final syllable gets geminated and acts as the coda of the first syllable, as in Table 7.

Table 7: Gemination from borrowed words with CV.CV/CV.CVC

\begin{tabular}{|c|c|c|}
\hline $\begin{array}{l}\text { Borrowed words with } \\
\text { CV.CV/CV.CVC }\end{array}$ & Gemination in SHB & Gloss \\
\hline gu.li & gul.li & 'bullet' \\
\hline go.di & gدd.d.di & 'mattress' \\
\hline ca.dor & cad.dor & 'shawl' \\
\hline je.ța & zit.ța & 'win' \\
\hline ti.la & til.la & 'hill' \\
\hline$f^{h} a \cdot k a$ & фuk.ka & 'hole' \\
\hline pa.ka & фak.ka & 'ripe' \\
\hline
\end{tabular}

\section{Optimality Theory and SHB Gemination}

Optimality theory (Prince \& Smolensky, 1993, 2004) is the latest development of classical generative phonology replacing rule-based models. It admits a universal set of constraints CON as ranked and violable. However, it is important to note that their ranking is not universal, and the differences give birth to cross-linguistic variation. In other words, languages differ from each other in giving priorities to some constraints over others. Due to such differences, the constraint which is minimally violated in one language may be maximally violated in another.

A formal mechanism of UG is GEN which serves to generate a large group of logically possible competing candidates for a given input while the function of another formal mechanism EVAL is to evaluate each candidate applying some constraint 
hierarchy to identify the most harmonic or optimal candidate as the output of the language. The candidate which satisfies the higher ranking constraint of the language is considered an optimal candidate even though the candidate violates the lowerranked constraints. Two main forces aim to decide the optimal candidate of a language: markedness and faithfulness constraints. Markedness constraints have no access to the input. They only evaluate the well-formedness of output candidates. On the other hand, faithfulness constraints have access to both input and output. Markedness constraints penalize candidates that violate their terms whereas faithfulness constraints penalize those candidates that have not been faithful to the input. When a candidate violates a constraint it is marked with an asterisk '*', whereas fatal violation is represented by an exclamation mark '!'. A pointing hand is used to mark an optimal candidate.

The universal ranking of constraints for gemination cited in Podseva (2002) is *GG1 $>{ }^{*} \mathrm{LL} \gg{ }^{*} \mathrm{NN}$. With a slight modification this ranking of constraints appears in Kawahara (2007) is *GG > ${ }^{*} \mathrm{LL} \gg{ }^{*} \mathrm{NN} \gg{ }^{*}$ GEMOBS. The investigation of SHB gemination process exhibits that in SHB the most geminable candidates are obstruents, nasals and laterals are less geminable and glides and rhotics are completely prohibited as geminate consonants. So, the ranking of constraints for SHB gemination based on this hierarchy is *GG*RR >*LL*NN>>*GEMOBS. Additional constraints necessary for this process are AGREECC, SYLLABLE CONTACT, and IDENT C/_V. AGREECC rules out the surface form in which adjacent consonants are not identical with the input. The positional faithfulness constraint IDENT C/_V violates the surface form whose features of the prevocalic segment in the output are different from the input.

Table 8: Representation of pod.mo > $\phi$ Jd.d. o in the optimality theory

\begin{tabular}{|c|c|c|c|c|c|c|c|c|}
\hline pod.mo & AGREECC & SYLCONT & $* \mathrm{GG}$ & $*_{\mathrm{RR}}$ & $* \mathrm{LL}$ & *NN & IDENT C/_V & *GEMOBS \\
\hline a) pod.mo & $* !$ & $* !$ & & & & & & \\
\hline b) & & & & & & & $*$ & $*$ \\
\hline c) фวm.mว & & & & & & $* !$ & & \\
\hline
\end{tabular}

The above Table 8 illustrates that the candidate with obstruent gemination is evaluated as optimal despite disobeying the constraints IDENTC/_V and *GEMOBS. This happens because it satisfies all the higher-ranked constraints. The candidate with sonorant gemination is eliminated by the constraint *NN, while the faithful candidate is eliminated by the constraint *AGREECC. Thus, the correct ranking of constraints is AGREECC, SYLCONT > *GG > *RR > *LL > *NN > IDENT C/_V, GEMOBS.

The above-mentioned constraints are identical regarding gemination and occur in the sonorant + obstruent medial clusters but their rankings are different. Here,

${ }^{1}$ G - Glide; L - Liquid; N - Nasal; GEMOBS - Geminate obstruent 
constraint IDENTC/_V is a higher-ranked constraint since the prevocalic segment of the winning output is the same as the input.

Table 9: Representation of kir.ton > kit.ton in the optimality theory

\begin{tabular}{l|c|c|c|c|c|c|c}
\hline kir.țon & AGREECC & IDENT C/_V & *GG & $*$ RR & *LL & *NN & *GEMOBS \\
\hline a) kir.ton & $* !$ & & & & & & \\
\hline b) morkit.ton & & & & & & & $*$ \\
\hline c) kir.ron & & $* !$ & & $*$ & & & \\
\hline
\end{tabular}

Table 9 demonstrates that the candidate with an obstruent gemination appears to be the optimal candidate because the faithful candidate violates the higher-ranked constraint AGREECC, and the candidate with a sonorant gemination violates another higher-ranked constraint *RR. This justifies the ranking of the constraints AGREECC, IDENTC/_V, *GG > * RR > *LL > *NN above *GEMOBS.

Our concern is to demonstrate that when the SHB speakers encounter two sonorants as the elemental composition of the heterosyllabic clusters, the less sonorous sound gets priority over the more sonorous sound. Table 10 is set to analyze this phenomenon in the optimality theory framework.

Table 10: Representation of pur.no > фun.no in the optimality theory

\begin{tabular}{|c|c|c|c|c|c|c|c|}
\hline pur.no & AGREECC & IDENT C/_V & *GG & ${ }^{*} \mathrm{RR}$ & *LL & *NN & GEMOBS \\
\hline a) pur.no & $* !$ & & & & & & \\
\hline b) & & & & & & $*$ & \\
\hline c) фur.ro & & $* !$ & & $*$ & & $*$ & \\
\hline
\end{tabular}

In the above table, it is evident that the surface form / Qun.no/ is evaluated as an optimal candidate as it satisfies all the higher-ranked constraints whereas the faithful candidate /pur.no/ violates higher-ranked constraint AGREECC, and another surface form / $\phi$ ur.ro/ is ruled out by the higher-ranked constraints IDENT C/_V and *RR. So the constraints AGREECC, IDENTC/_V, *GG > *RR > * $\mathrm{LL} \gg$ > outrank the constraints *NN, *GEMOBS

However, the above-mentioned constraints are not adequate for the explanation of the derivation from the CV.CV or CV.CVC syllable structure into the geminate syllable CVC.CV or CVC.CVC. To establish constraints of this gemination, we need to take into account metrical stress in SHB. The prominent stress pattern of SHB is disyllabic where the first syllable attracts stress, and SHB speakers prefer heavy syllables to be considered as stressed for example /'huk.na/ ('HL) ('CVC.CV) 'thin', /'gin.na/ ('HL) 
('CVC.CV) 'hate'. In SHB, the CVC syllable is treated as a heavy syllable for its two moraic values. In the case of borrowed words consisting of CV.CV/CV.CVC structure, the first syllable is light. This leads to the transformation of the first syllable (stressed syllable to a heavy syllable) resulting into a CVC structure in SHB. This phenomenon necessitates the constraint stress by weight position (SWP), which eliminates the candidate that violates the principle that stressed syllable must be heavy. Alternatively, it can be said that this constraint assigns a violation if the stressed syllable is not heavy. Additional relevant constraints are MAX-IO, DEP-IO, and *GEM. MAX-IO assigns a violation if the sounds in the input do not have output correspondence. On the contrary, DEP-IO assigns a violation if the sounds in the output do not have input correspondence. The constraint *GEM disallows gemination.

Table 11: Representation of gu.li > gul.li in the optimality theory

\begin{tabular}{l|c|c|c|c}
\hline gu.li & SWP & MAX-IO & DEP-IO & *GEM \\
\hline a) gu.li & $* !$ & & & \\
\hline b) gul.li & & & $*$ & $*$ \\
\hline c) gul & & $* !$ & & \\
\hline
\end{tabular}

As seen in Table 11, the first surface form cannot be considered an optimal candidate due to its violation of a higher-ranked constraint SWP. The third surface form with the deletion of the final syllable of the input assigns a violation of the higherranked constraint MAX-IO. In the optimal surface candidate that is /gul.li/ violation of lower-ranked constraints occurs at the expense of satisfying the higher-ranked constraints SWP and MAX-IO. Henceforth, the constraint ranking required for this phenomenon is SWP, MAX-IO >>DEP-IO, *GEM.

\section{Conclusion}

This paper demonstrated how systematically SHB speakers adopt loanwords by modifying them into gemination. Preferring obstruents over sonorants, the SHB gemination process corroborates the universal view that sonorants are marked geminates. Because the sonorant segment creates less constriction duration with the singleton in the spectrum, the insufficient distinction causes misperception in the speakers' minds driving them to avoid geminate sonorants. However, an interesting observation is that when the input consists of two sonorants, SHB speakers prefer the less sonorous one, which proves that sonorant gemination is not completely absent from SHB. Henceforth, in SHB the most geminable candidates are obstruents, followed by nasals and laterals, while glides and rhotics are not geminable. 
As far as the ranking of constraints within OT is concerned, it is noted that in the case of consonant clusters of different sonority, the order is AGREECC, SYLCONT $>$ *GG $\gg * \mathrm{RR} \gg{ }^{*} \mathrm{LL} \gg *^{*} \mathrm{NN} \gg$ > IDENT C / _V, GEMOBS. In respect to consonant clusters of equal sonority, the order is AGREECC, IDENT C/_V > ${ }^{*} G G>*^{*} R R>*^{*} L L>* N N>>$ *GEMOBS. Besides, it is also observed in SHB when the cluster consists of a sonorant + sonorant sequence, the nasal sound retains its position. The ranking of constraints for such variation is AGREECC, SYLCONT, IDENTC/_V $>*^{*} G G \gg *^{*} R R>*^{*} L L>*^{*} N N$. In respect to the gemination process where input forms of the CV.CVC or CVC.CV syllable structures are transferred into surface forms of a CVC.CVC or CVC.CV, the ranking of constraints is SWP, MAX-IO >> DEP-IO, *GEM.

\section{References}

Anwar, M. (2013). Sylhet: bhasha boichitra o shabda shampad (A phenomenon of sylheti: Language and word bank). Ittadi Grantha Prokash.

Beckman, J. (1998). Positional faithfulness. Doctoral Dissertation. University of Massachusettes, Amherst.

Blevins, J. (1995). The syllable in phonological theory. In J. Goldsmith (Ed.), The Handbook of Phonological Theory. USA: Blackwell Publishing.

Boersma, P. (1998). Functional typology: Formalizing the interaction between articulatory and perceptual drives. The Hague: Holland Academic Graphics.

Catford, J. C. (1977). Fundamental Problems in Phonetics. Edinburgh: Edinburgh University Press.

Clements, G. N. (1990). The Role of the Sonority Cycle in Core Syllabification. In J. Kingston \& M. Beckman (Eds.), Papers in Laboratory Phonology I: Between the Grammar and Physics of Speech (pp. 283-333). Cambridge: Cambridge University Press.

Davis, S. (1998). Syllable in optimality theory. Journal of Korean Linguistics, 23, 181-211.

Davis, S. (2011). Geminates. In M. van Oostendorp et al. (Eds.), The Blackwell Companion to Phonology, (Vol. 2, pp. 873-897). Oxford: Wiley-Blackwell.

Dutta, H. (2017). Strength asymmetries and Pali geminates: An OT account. The EFL journal 8. pp. 49-65.

Flemming, E. (1996). Evidence for Constraints on Contrast: The dispersion theory of contrast. UCLA working papers in Phonology 1, pp. 86-106.

Flemming, E. (2004). Contrast and perceptual distinctiveness. In B. Hayes, R. Kirchner \& D. Steriade (Eds.), Phonetically based phonology (pp. 232-276). Cambridge: Cambridge University Press.

Gouskova, M. (2002). Falling sonority onsets, loanwords and syllable contact. In M. Andronis, E. Debenport, C. Ball, H. Elston, \& S. Neuvel (Eds.), CLS 37: The main session. Papers from the 37th Meeting of the Chicago Lingustic Society (Vol. 1, pp. 175-186). CLS.

Ito, J., \& Mester, A. (1999). The phonological lexicon. In N. Tsujimura (Ed.), The Handbook of Japanese Linguistics (pp. 62-100). Oxford: Blackwell. 
Ito, J., \& Mester, A. (2006). Systematic markedness and faithfulness. In J. E. Cihlar et al. (Eds.), Papers from the $39^{\text {th }}$ Annual Meeting of the Chicago Linguistic Society (pp. 665-689). Chicago: Chicago Linguistic Society.

Kenstowicz, M. (1994). Phonology in Generative Grammar. Oxford: Blackwell.

Kubozono, H. (2017). Introduction to the Phonetics and Phonology of Geminate Consonants. Oxford University Press.

Ladefoged, P., \& Ian, M. (1997). The Sounds of the World's languages. UK: Blackwell.

Liljencrants, J., \& Lindblom, B. (1972). Numerical simulation of vowel quality systems. The Role of Perceptual Contrast Language, 48, pp. 839-862. doi:10.2307/411991

Lindblom, B. (1986). Phonetic universals in vowel system. In J. Ohala \& J. Jaegar (Eds.), Experimental Phonology, 13-44. Orlando: Academic Press.

Kawahara, S. (2007). Sonorancy and geminacy. In L. Bateman et. al (Eds.), University of Massachusetts Occasional Papers in Linguistics 32: Papers in OT.III, (pp. 145-186). Amherst, Mass.: GLSA

Kubozono, H. (2017). Introduction to the phonetics and phonology of geminate consonants. Oxford University Press.

Ohala, J. (1993). The phonetics of sound change. In C. Jones (Eds.), Historical Linguistics: Problems and Perspectives (pp. 237-278). London: Longman.

Pajak, B. (2009). Contextual constraints on gemination: The case of Polish. BLS 35, 1, pp.269280. http://dx.doi.org/10.3765/bls.v35i1.3617

Padgett, J. (2003). Contrast and Post-Velar Fronting in Russian. Natural Language \& Linguistic Theory 21, 39-87. https://doi.org/10.1023/A:1021879906505

Podseva, R. (2002). Segmental constraints on geminates and their implications for Typology. Paper presented at January 2002 Annual Meeting of the Linguistic Society of America, San Francisco, 3-6 Jan.

Prince, A., \& Smolensky, P. (1993/2004). Optimality theory: Constraint interaction in generative grammar. Oxford: Blackwell.

Rice, K. (1992). On Deriving Sonority: A Structural Account of Sonority Relationships. Phonology, 9(1), 61-99. Retrieved from http://www.jstor.org/stable/4420046.

Taylor, M. (1985). Some patterns of geminate consonants. The University of Chicago Working Papers in Linguistics 1, pp. 120-129.

Vennemann, T. (1988). Preference laws for syllable structure and the explanation of sound change. Berlin: Mouton de Gruyter. 